\title{
TOMASZ BuRZYŃSKI
}

Uniwersytet Śląski w Katowicach

iD ORCID https://orcid.org/0000-0003-3780-0020

\section{MIĘDZY REPRODUKCJĄ A ZMIANĄ SYSTEMOWĄ. CZASOPISMA LITERACKIE W SPOŁECZNYM SYSTEMIE LITERATURY}

\author{
BETWEEN REPRODUCTION AND SYSTEMIC CHANGE. LITERARY MAGAZINES \\ IN THE SOCIAL SYSTEM OF LITERATURE
}

The article aims to outline the role of literary periodicals in the social system of literature from a perspective of processes that take part in the accumulation of both cultural capital and social capital. In this sense, the paper is an attempt to incorporate a sociological perspective into the theory of literature in order to provide a more informed view on social and cultural processes that are mediated by literary periodicals of diversified kind. By referring to the notions of embodied and institutional cultural capital (Pierre Bourdieu) as well as social capital (Robert D. Putnam, Francis Fukuyama), the paper examines the dialectic of system reproduction and morphogenetic change in terms of processes that organize the functioning of literature conceived of a specific kind of social system.

Keywords: literature, literary periodicals, cultural capital, social capital, social system.

\section{МЕЖДУ РАЗМНОЖЕНИЕМ И СИСТЕМНЫМ ИЗМЕНЕНИЕМ. ЛИТЕРАТУРНЫЕ ЖУРНАЛЫ В СОЦИАЛЬНОЙ ЛИТЕРАТУРНОЙ СИСТЕМЕ}

Статья призвана очертить роль литературной периодики в социальной системе литературы с точки зрения процессов, которые участвуют в накоплении как культурного капитала, так и социального капитала. В этом смысле статья представляет собой попытку включить социологическую перспективу в теорию литературы для того, чтобы дать более информативный взгляд на социально-культурные процессы, которые происходят при посредничестве разнообразных литературных периодических изданий. Ссылаясь на понятия овеществленного 
и институционального культурного капитала (Пьер Бурдье), а также социального капитала (Роберт Д. Путнам, Фрэнсис Фукуяма), в статье рассматривается диалектика воспроизводства системы и морфогенетических изменений в рамках процессов организации функционирования литературы, задуманной как особый вид социальной системы.

Ключевые слова: литература, литературная периодика, культурный капитал, общественный капитал, социальная система.

\section{WSTĘP}

Fundamentem socjologicznych rozważań nad literaturą jest założenie, że jest ona zjawiskiem immanentnie społecznym. Z jednej strony, proces powstawania dzieła literackiego zachodzi w określonych warunkach społecznych, które mogą być zarówno źródłem inspiracji dla autora tekstu, jak i, co często uchodzi uwadze studiów literaturoznawczych, punktem wyjścia dla czytelnika dzieła literackiego, który, interpretując i szukając sensu dzieła literackiego, sięga po repertuar wiedzy potocznej składającej się na tzw. strukturę idealną ${ }^{1}$ danego społeczeństwa. Z drugiej strony, procesy podmiotowej interpretacji dzieł literatury pięknej i popularnej stanowią istotne wskazówki w kreśleniu socjologicznego portretu czytelnika i zjawiska czytelnictwa rozumianego jako normatywnie ugruntowana praktyka społeczna. Wówczas wybór tekstów literackich, płaszczyzna ich zrozumienia i interpretacji wpisują się we wzory uczestnictwa w kulturze charakteryzujące jednostki wywodzące się ze środowisk społecznych o dających się jednoznacznie zdefiniować i zmierzyć charakterystykach demograficznych i klasowo-warstwowych ${ }^{2}$. Innymi słowy, socjologiczność literatury wynika właśnie z jej powiązania z procesami społecznego konstruowania i dekonstruowania znaczeń, które przebiegają w ramach jakiegoś przed-literackiego porządku społecznego, w którym jednostki aktywnie uczestniczą jako współtwórcy znaczeń i dyskursów kultury symbolicznej.

\footnotetext{
${ }^{1}$ P. Sztompka, Society in Action. The Theory of Social Becoming, Polity Press, Cambridge 1991.

${ }^{2}$ W. Świątkiewicz, Zróżnicowanie społeczne a uczestnictwo w kulturze, Wydawnictwo Uniwersytetu Śląskiego, Katowice 1984.
} 
Jedną z konsekwencji tezy o immanentnie socjologicznej naturze literatury pięknej i popularnej jest postrzeganie twórczości literackiej w kategoriach modelu komunikowania społecznego, w którym nadawca (autor) wykorzystuje zinstytucjonalizowane środki przekazu w celu rozpowszechniania określonych wartości poznawczych i estetycznych ${ }^{3}$. Charakter literackiego procesu komunikowania społecznego jest natomiast odzwierciedleniem ogólniejszych trendów i tendencji modernizacyjnych, ale można założyć, że wraz z wdrażaniem podstawowych instytucji nowoczesności (tj. systemy społeczno-techniczne, racjonalność rynkowa, państwo narodowe) model komunikowania społecznego poprzez twórczość literacką przybiera cechy procesów komunikowania masowego. To szczególne nachylenie badawcze jest charakterystyczne dla socjologii literatury i dla badań z zakresu badań kulturowych (cultural studies) czy medioznawstwa (media studies).

Bez względu na obraną płaszczyznę badawczą socjologiczne myślenie o literaturze koncentruje się na pokazaniu, że twórczość literacka nie jest jedynie zbiorem tekstów kultury podlegających prawom i prawidłowościom kształtujących obszar kultury symbolicznej, ale jest także zbiorem ustrukturyzowanych praktyk społecznych polegających na procesach wymiany informacji i konstruowania wiedzy potocznej ${ }^{4}$. Myślenie takie wykracza zdecydowanie poza zasadnicze paradygmaty klasycznego i współczesnego literaturoznawstwa i wykazuje spójność teoretyczną i konceptualną ze studiami wchodzącymi w skład badań kulturowych. Można, co prawda, postrzegać badania kulturowe jako część składową wchodzącą w zakres teorii literaturoznawczych ${ }^{5}$, lecz należy w tym miejscu pamiętać, że badania kulturowe mają szerszy zakres tematyczny badań oraz inny rodowód, wywodzący się z tzw. szkoły frankfurckiej, niż tradycyjne, dogmatycznie pojmowane literaturoznawstwo.

\footnotetext{
${ }^{3}$ Zob. R.D. Sell, Literature as Communication. The Foundations of Mediating Criticism, John Benjamins Publishing Company, Amsterdam 2000.

${ }^{4}$ P. Berger, T. Luckmann, Społeczne tworzenie rzeczywistości. Traktat z socjologii wiedzy, przeł. J. Niżnik, Wydawnictwo Naukowe PWN, Warszawa 2010.

${ }^{5}$ Zob. A. Burzyńska, M.P. Markowski, Teorie literatury XX wieku, Wydawnictwo Znak, Kraków 2007.
} 
Tekst ten podąża właśnie śladem płaszczyzny badawczej, która koncentruje się na poszukiwania obszarów wspólnych na teorii socjologicznej i współczesnej teorii literatury, a zasadniczym celem tego artykułu jest pokazanie miejsca i roli czasopism literackich w obszarze twórczości literackiej rozumianej jako sui generis typ systemu społecznego. W tym specyficznym kontekście interpretacyjnym funkcja czasopism literackich jest dwojaka i odnosi się do procesów reprodukcji systemu literatury w drodze akumulacji kapitału kulturowego i zmiany tegoż systemu w trakcie mobilizacji zasobów kapitału społecznego.

\section{CZASOPISMA LITERACKIE W PERSPEKTYWIE MYŚLI JÜRGENA HABERMASA}

Jako periodyki pełniące funkcje popularyzatorskie i naukowo-krytyczne czasopisma literackie są niewątpliwie znaczącym elementem systemu społecznego literatury. Klasyczne ujęcie tego zagadnienia kieruje naszą uwagę w stronę myśli społecznej Jürgena Habermasa oraz koncepcji literackiej sfery publicznej ${ }^{6}$. Istota sfery publicznej odnosi się do wykształcania się przestrzeni dialogu obywatelskiego, w którym partykularne interesy jednostkowe zostają z czasem przekształcone w dbanie o dobra publiczne. „Sfera publiczna rozpościera się w polu napięcia między państwem a społeczeństwem [...]"7 , co powoduje, że jest to przestrzeń swobodnej i zorganizowanej aktywności obywatelskiej, która z jednej strony pełni funkcje kontrolne wobec aparatu władzy państwowej (pamiętamy, że sfera publiczna to przestrzeń, w której kształtuje się opinia publiczna), z drugiej natomiast charakteryzuje się występowaniem oddolnych inicjatyw społecznych i politycznych, stanowiących uzupełnienie działań struktur politycznych.

Pojęcie sfery publicznej nie odnosi nas do jakiejś konkretnej przestrzeni geograficznej czy też do jakiegoś dającego się łatwo

\footnotetext{
${ }^{6}$ J. Habermas, Strukturalne przeobrażenia sfery publicznej, przeł. W. Lipnik, M. Łukasiewicz, Wydawnictwo Naukowe PWN, Warszawa 2007.

7 Tamże, s. 279.
} 
zdefiniować i wyszczególnić systemu lub instytucji społecznej. Jest to raczej termin opisujący zorganizowane działania społeczne przebiegające $w$ wielu kontekstach organizacyjnych i instytucjonalnych, które obejmują takie różnorodne ośrodki skupienia, jak: kawiarnie, klubo-kawiarnie, stowarzyszenia, ruchy społeczne, fundacje, kluby literackie oraz media masowe. W społeczeństwie nowoczesnym pierwszoplanowa rola $\mathrm{w}$ tworzeniu sfery publicznej przypisywana jest właśnie środkom komunikowania masowego, a przede wszystkim internetowi jako platformie umożliwiającej wymianę nieuregulowanych poglądów i swobodnej dyskusji.

Teorie dotyczące roli mediów w kształtowaniu się sfery publicznej koncentrują naszą uwagę na tzw. literackiej sferze publicznej. „Rozwijająca się sfera publiczna na kanwie tematów literackich i kulturowych stanowiła zaczątek dla późniejszych funkcji politycznych; było to laboratorium ćwiczebne dla publicznych rozważań. Habermas nazywa ją literacką sferą publiczną" ${ }^{\text {. }}$ Literacka sfera publiczna staje się zatem areną wymiany poglądów i wartości, umożliwiającą ukształtowanie dyskursywnych ram dla kultury zaufania'. Zaufanie jest jednym z fundamentów liberalnego modelu demokracji przedstawicielskiej, w którym oczekuje się, że aktywność obywatelska jest rezultatem historycznie zakumulowanych wzorców ufności praktykowanej zarówno w wymiarze interpersonalnym, jak i w wymiarze relacji pomiędzy obywatelem a siecią instytucji społecznych (tj. społeczeństwo obywatelskie) oraz państwowych. Z tej perspektywy doświadczenie dyskusji, wspólna praca interpretacyjna, cykliczność spotkań (wynikających z cyklicznego charakteru czasopism literackich) budowały atmosferę uogólnionej ufności, która $\mathrm{z}$ biegiem czasu przekształcała się w kulturę zaufania, czyli zespół normatywnych i aksjologicznych oczekiwań względem alokacji i odwzajemniania ufności charakteryzujących jednostki funkcjonujące w podobnym

8 A. Ochman, Zarys koncepcji Habermasowskiej sfery publicznej, „Studia Teologiczno-Historyczne Śląska Opolskiego” 2015, nr 35, s. 28.

9 P. Sztompka, Trust. A Sociological Theory, Cambridge University Press, Cambridge 1999. 
uniwersum symbolicznym, a więc operujące zbliżonym zestawem znaczeń, wartości i norm kultury ${ }^{10}$.

Koncepcja literackiej sfery publicznej wpisuje się zatem w krąg rozważań funkcjonalno-strukturalnych. Habermas i jego następcy udowadniają bowiem, że literaturę (lub ściślej czasopisma literackie) można postrzegać w kategoriach jej funkcji w kształtowaniu określonych form porządku społecznego. Co więcej, uczestnictwo w kulturze poprzez zrutynizowane praktyki czytelnicze rodzi konsekwencje emergentne, ponadjednostkowe. Strukturalną konsekwencją praktyk czytelniczych jest wytworzenie się uogólnionego klimatu zaufania, w którym ufność (lub jej brak) nie jest li tylko wyborem jednostkowym aktora społecznego, ale staje się oczekiwaniem kulturowym przekazywanym z pokolenia na pokolenie w procesach socjalizacji i akulturacji.

\section{LITERATURA JAKO SYSTEM SPOŁECZNY}

Koncepcja literackiej sfery publicznej nie jest pozbawiona ograniczeń, które wydają się szczególnie istotne zwłaszcza z perspektywy teorii literatury. Teoria Habermasa jest skoncentrowana na postrzeganiu literatury, w tym czasopism literackich, przede wszystkim w kategoriach środka do celu, jakim jest wytworzenie się politycznej sfery publicznej. Literatura nie jest zatem centralnym problemem badawczym i ustępuje miejsca problematyce kształtowania się postaw obywatelskich w ramach rozwijającego się nowoczesnego systemu demokracji liberalnej. Z tych względów myśl społeczna Habermasa nie dotyka tak istotnych dla współczesnego literaturoznawstwa problemów, jak społeczne procesy produkcji i interpretacji znaczeń kultury symbolicznej, a więc zagadnień badawczych, które pojawiają się na styku odbiorcy i nadawcy tekstu literackiego, czyli w płaszczyźnie literackości rozumianej jako społeczny model komunikowania masowego. Nie jest to, rzecz jasna, przytyk w kierunku samej koncepcji literackiej sfery publicznej, która, co zrozumiałe, została ukształtowana raczej w sferze zainteresowań socjologii polityki, niż teorii literatury.

${ }^{10}$ Tegoż, Socjologia. Analiza społeczeństwa, Wydawnictwo Znak, Kraków 2007. 
Z punktu widzenia literaturoznawstwa i socjologii literatury istotne jest zatem zaprezentowanie modelu teoretycznego, który ujmuje literaturę jako szczególny rodzaj systemu społecznego skonstruowanego na podstawie jasno wyróżnionych i typowych form komunikowania społecznego. Teoretyczne źródła tego modelu biją w dwóch konceptualizacjach porządku społecznego odwołujących się do pojęcia systemu społecznego. Z jednej strony, mam na myśli teorię autopojetycznych systemów społecznych Niklasa Luhmanna. Istotą koncepcji Luhmanna jest kategoria autopojezy, czyli samoorganizowania się systemu społecznego w ramach własnej struktury:

[...] system jest w zupełności wytwarzany przez operacje i potem też tak definiowany $\mathrm{w}$ obserwacji. Jeśli mamy operację jako producenta systemu, to musimy tak ustawić teorię, aby odnosiła się ona do tej operacji, a to oznacza, że teoria systemowa i teoria komunikacji muszą być pojmowane łącznie. Gdyż tą operacją, jak powiedziałem już, jest komunikacja ${ }^{11}$.

W takim rozumieniu systemy społeczne (w tym społeczeństwo pojmowane jako ogólna kategoria refleksji socjologicznej) nie są tworami zbudowanymi z jednostek czy mniejszych grup społecznych, ale ze zdarzeń komunikacyjnych czyniących system społeczny samoorganizującym się bytem, w którym produkcja i wymiana informacji jest warunkiem sine qua non dla przetrwania systemu jako całości.

Do wymiaru zdarzeń lub - szerzej - praktyk społecznych odwołuje się drugie z nachyleń teoretycznych, które legło u podstaw postrzegania literatury jako systemu społecznego. W perspektywie teorii strukturyzacji Anthony’ego Giddensa system społeczny postrzegany jest w kategoriach obserwowalnego przejawu struktury społecznej, który przybiera formę ustrukturyzowanych, uporządkowanych w czasie i w przestrzeni powtarzalnych praktyk społecznych $^{12}$. Poprzez analogie do rozróżnienia miedzy langue i parole,

\footnotetext{
${ }^{11}$ N. Luhmann, Einführung in die Systemtheorie, Carl Auer Verlag, Heidelberg 2006. Cyt za: M. Głażewski, Teoria systemów autopojetycznych Niklasa Luhmanna - między metafizyka a metabiologia, , Przegląd Pedagogiczny” 2009, nr 1, s. 39-55.

12 A. Giddens, Stanowienie społeczeństwa. Zarys teorii strukturyzacji, przeł.

S. Amsterdamski, Wydawnictwo Zysk i S-ka, Poznań 2003.
} 
wprowadzonym przez Ferdinanda de Saussure’a dla zrozumienia istoty języka, struktura społeczna przybiera kształt ukrytej „gramatyki" życia społecznego ${ }^{13}$, systemy społeczne stają się natomiast widzialnymi przejawami (na podobieństwo aktów komunikacji językowej) wspominanych reguł i prawidłowości strukturalnych.

Pojmowanie literatury jako szczególnego rodzaju systemu społecznego opiera się zatem na przekonaniu, że pojęcie to nie odnosi się tylko do korpusu tekstów pisanych, spełniających określone warunki artystyczne i poznawcze, które wchodzą w skład dorobku kultury symbolicznej typowego dla danego społeczeństwa. Społeczny system literatury jest zatem złożony $\mathrm{z}$ reprodukujących się w czasie i przestrzeni praktyk znaczeniotwórczych (tj. praktyki produkcji i interpretacji znaczeń literackich), reguł językowych, retorycznych i edycyjnych kształtujących literaturę oraz wszelkich instytucji lub podmiotów jednostkowych, które zainteresowane są tworzeniem i rozpowszechnianiem wartości artystycznych i poznawczych utożsamianych z literaturą piękną i popularną.

Społeczny system literatury nosi znamiona systemu samoreprodukującego się: procesy tworzenia i interpretacji dzieła literackiego nie zachodzą w symbolicznej próżni, tylko stają się wypadkową zanurzenia praktyk twórczych i interpretacyjnych (od-twórczych) w literackim uniwersum znaczeń, wartości i symboli. W ten sposób zostaje spełniony postulat Ronalda Barthes'a o dziele literackim jako o przestrzeni intertekstualnej ${ }^{14}$. Z kolei praktyki znaczeniotwórcze (tj. społeczne działania nakierowane na produkowanie i użytkowanie znaczeń kultury ${ }^{15}$ ) zakładają społeczną aktualność zdarzeń komunikacyjnych jako „aktywność, w której dialog pomiędzy podmiotem a Innym oraz jego społeczny kontekst zostają zainwestowane w przebieg tego samo działania"16. Społeczny sys-

${ }^{13}$ Zob. P. Sztompka, Society in Action...

${ }^{14}$ Zob. R. Barthes, Śmierć autora, przeł. M.P. Markowski, „Teksty drugie: teoria literatury, krytyka, interpretacja” 1999, nr 1/2.

${ }^{15}$ W. Kalaga, Culture and Signification, w: K. Knauer, S. Murray (red.), Britishness and Cultural Studies. Continuity and Change in Narrating the Nation, Wydawnictwo Śląsk, Katowice 2000.

${ }^{16}$ R. Barthes, Theory of the Text, w: R. Young (red.), Untying the Text: a PostStructuralist Reader, Routledge, London-New York 1981, s. 36. Przeł. - T.B. 
tem literatury jest zatem areną kształtowania się znaczeń, w której podmioty jednostkowe, zbiorowe oraz instytucjonalne uczestniczą w procesach konfliktu i negocjacji, współtworząc znaczenie dzieła literackiego.

\section{CZASOPISMA LITERACKIE W SPOŁECZNYM SYSTEMIE LITERATURY}

Społeczny system literatury to byt dynamiczny, łączący w sobie działania różnorodnych podmiotów. W ten sam sposób znaczenie tekstu literackiego to twór dynamiczny, gdyż jest ono społecznie wytwarzane w toku wzajemnie na siebie oddziałujących praktyk znaczeniotwórczych. Ze względu na fakt, że siły społeczne tworzące społeczny system literatury uczestniczą w procesach tworzenia i interpretacji tekstu literackiego, a więc przekształcania jednych znaczeń i wartości w inne, proponuję odwołać się do terminu kapitał jako pojęcia chyba najbardziej uprawomocnionego do opisu przetwarzania wartości i przemian wartości we współczesnym społeczeństwie.

Rola czasopism literackich w społecznym systemie literatury sprowadza się do ich roli w akumulacji i reprodukcji dwóch form kapitału (tj. kapitału kulturowego i kapitału społecznego). Po pierwsze, jest to kapitał kulturowy, czyli pojęcie odnoszące się do praktyk uczestnictwa w kulturze i wskazujące na takie dyspozycje jak gust, dobre maniery, znajomość konwencji i form charakterystycznych dla wytworów zaliczanych do tzw. kultury wysokiej ${ }^{17}$. Z perspektywy jednostki (tj. czytelnika) kapitał kulturowy przejawia się w formie ucieleśnionej (embodied cultural capital) jako rezultat internalizacji wzorów uczestnictwa w kulturze $\mathrm{w}$ toku procesów socjalizacji pierwotnej, edukacji oraz poszerzania własnych zainteresowań poza sferą instytucjonalnego szkolnictwa. Wówczas kapitał kulturowy przekształca się w habitus jednostki, czyli zespół

${ }_{17}$ P. Bourdieu, The Forms of Capital, w: J.G. Richardson (red.), Handbook of Theory and Research for the Sociology of Education, Greenwood, New York 1986; P. Bourdieu, J.C. Passeron, Reprodukcja. Elementy teorii systemu nauczania, przeł. E. Neyman, Wydawnictwo Naukowe PWN, Warszawa 2006. 
rzeczywistych praktyk uczestnictwa w kulturze, które jednostka postrzega jako naturalne, wynikające z ugruntowanych nawyków. W formie instytucjonalnej (institutional cultural capital) kapitał kulturowy jest akumulowany przez instytucje, które w społeczeństwie pełnią funkcję regulacyjną względem konsumpcji treści kulturowych (np. uniwersytety, kluby literackie, czasopisma literackie i literaturoznawcze). Podobną rolę pełnią osoby zawodowo zajmujące się krytyka literacką, przy czym ich działalność winna być zinstytucjonalizowana, czyli prowadzona w oparciu o wiarygodną organizację lub środek komunikowania masowego ${ }^{18}$.

W perspektywie akumulacji kapitału kulturowego należy odczytywać naukowo-krytyczną funkcję czasopism literackich jako periodyków poświęconych badaniom literaturoznawczym oraz poszukiwaniom teorii, konceptualizacji i dyskursów umożliwiających uprawnianie akademickiej krytyki literackiej (np. „Teksty Drugie”, „ER(R)GO”, „Przegląd Rusycystyczny”). W tym kontekście czasopisma literackie biorą czynny udział w kształtowaniu się kanonu literackiego obejmującego zbiór tekstów, których znajomość jest wyznacznikiem dobrego gustu literackiego i znajomości tekstów literatury narodowej czy powszechnej. Sama instytucja kanonu literackiego jest najdobitniejszym chyba przykładem procesów akumulacji kapitału kulturowego: mówimy o kanonie literackim człowieka wykształconego, a znajomość tekstów wchodzących w jego skład jest dla jednostki rodzajem zasobu, który jest wykorzystywany w zdobywaniu kompetencji edukacyjnych i zawodowych, czyli w toku udziału w procesach ruchliwości społecznej.

Z punktu widzenia społecznego systemu literatury zaangażowanie czasopism literackich w krzewienie kanonu literatury może być traktowane, co jest głównie podnoszone przez przedstawicieli teorii krytycznej, jako rodzaj przemocy symbolicznej, czyli mechanizmów formowania się fałszywej świadomości, w ramach której przedstawiciele warstw podporządkowanych stają się skłonni postrzegać rze-

${ }^{18} \mathrm{~W}$ ten sposób, na przykład, trudno jest określić ludzi, którzy parają się dorywczą krytyką treści kulturowych w internecie w kategoriach ról społecznych utożsamianych z akumulacją instytucjonalnego kapitału kulturowego. 
czywistość w kategoriach narzuconych przez reprezentantów elit dominujących ${ }^{19}$. Pomijając Marksowskie i marksistowskie podwaliny pod teorię przemocy symbolicznej, można zauważyć, że pojęcie to wyraża zdolność społecznego systemu literatury do samo-reprodukcji, czyli do zachowania ciągłości wartości i norm, na których zbudowana jest komunikacja literacka. Społeczny system literatury jest organizmem, w którego żyłach płynie specyficzny rodzaj informacji, którego cyrkulacja jest sterowana poprzez autorytet instytucji posiadających kapitał kulturowy (np. czasopism literackich). Instytucje te, biorąc czynny udział w kształtowaniu się zainteresowań i gustów czytelniczych, stają się jednocześnie motywacją dla podejmowania prób pisarskich przez młode pokolenia twórców. Ponadto, co dotychczas nie było przedmiotem naszego wywodu, czasopisma literackie stają się naturalnym wydawcą dla młodych pisarzy, którzy pod egidą tego rodzaju periodyków szlifują swe literackie umiejętności w zakresie tworzenia małych form literackich.

O ile akumulacja kapitału kulturowego w społecznym systemie literatury jest odpowiedzialna za reprodukcje tegoż systemu, o tyle akumulacja kapitału społecznego jest czynnikiem zmian morfogenetycznych zachodzących w ramach systemu literatury. Morfogeneza to kluczowe pojęcie współczesnej socjologii teoretycznej wskazujące na udział zorganizowanych działań podmiotowych w procesach zachodzenia zmian w systemach i strukturach społecznych ${ }^{20}$. Kapitał społeczny odnosi się natomiast do występowania norm regulujących współdziałanie, osiąganie wspólnych celów poprzez kształtowanie atmosfery wzajemnego zaufania, solidarności, myślenia w kategoriach wspólnotowych ${ }^{21}$. Przestrzenią akumu-

${ }^{19}$ P. Bourdieu, J. Passeron, Reprodukcja...

${ }^{20}$ M. Archer, Realist Social Theory. The Morphogenetic Approach, Cambridge University Press, Cambridge 1995.

${ }^{21}$ R.D. Putnam, Making Democracy Work: Civic Traditions in Modern Italy, Princeton University Press, Princeton 1993; F. Fukuyama, Trust: Social Virtues and the Creation of Prosperity, Free Press, New York 1995; A.B. Seligman, The Problem of Trust, Princeton University Press, Princeton 1997; R.D. Putnam, Bowling Alone: The Collapse and Revival of American Community, Simon and Schuster, New York 2000. 
lacji kapitału społecznego są ruchy społeczne, dobrowolne stowarzyszenia, oddolne inicjatywy obywatelskie podejmowane w sferze politycznej, ekonomicznej czy kulturowej. Procesy akumulacji kapitału społecznego bez wątpienia stoją za oddolnymi inicjatywami kulturowymi, w toku których produkty kultury powstają w pewnym oddaleniu od instytucji rozpowszechniania kultury wysokiej (tj. instytucji akumulujących i przetwarzających kapitał kulturowy) oraz przemysłu rozrywkowego (tj. instytucji akumulujących i przetwarzających kapitał finansowy). Innymi słowy, kapitał społeczny staje się ważnym elementem spontanicznego tworzenia kultury, często w oparciu o styczności bezpośrednie i współdziałanie w ramach lokalnych inicjatyw ${ }^{22}$.

$\mathrm{W}$ procesach akumulacji kapitału społecznego na rzecz oddolnych inicjatyw kulturalnych niebagatelne znaczenie przypisywane jest specyficznemu typowi czasopisma kulturalnego, jakim jest fanzin:

Na świecie pierwsze fanziny pojawiły się w latach 30. XX wieku w USA wśród fanów science fiction, którzy początkowo komunikowali się poprzez ogłoszenia i działy listów w magazynach poświęconych literaturze science fiction, a $\mathrm{z}$ czasem przenieśli te dyskusje do samodzielnie wydawanych czasopism. W kolejnych latach praktycznie każdy nowy nurt w kulturze czy jakiekolwiek działania o charakterze społecznym, miały swoje własne niezależne wydawnictwa. Szczególne nasilenie tego zjawiska nastąpiło w okresie kontrkultury lat 60., a masowe upowszechnienie samych fanzinów nastąpiło w połowie lat 70. przy okazji eksplozji muzyki punk, początkowo w Wielkiej Brytanii i USA, a zaraz potem na całym świecie ${ }^{23}$.

Fanzin jest zatem rodzajem nieprofesjonalnego pisma tworzonego przez grupę miłośników jakiejś formy ekspresji kulturowej (np. literatura science fiction, gry wideo, muzyka alternatywna), który jest wydawany bez udziału kapitału zewnętrznego i dystrybuowany stosunkowo niewielkiej grupie zainteresowanych odbiorców często w cenie pokrywającej jedynie koszty produkcji i dystrybucji.

\footnotetext{
${ }^{22}$ Antonina Kłoskowska pisze w tym kontekście o modelu kultury aktualnie społecznej. Zob. A. Kłoskowska, Socjologia kultury, Wydawnictwo Naukowe PWN, Warszawa 2007.

${ }^{23}$ B. Głowacki, Prasa trzeciego obiegu w okresie przełomu, „Kultura - Media Teologia” 2010, nr 3, s. 34.
} 
Czasopisma tego rodzaju powstają w obiegu kultury nieoficjalnej (w czasach PRL-u w Polsce mówiono o trzecim obiegu kultury, odróżniając go od pierwszego obiegu kultury oficjalnej i drugiego obiegu kultury opozycyjnej ${ }^{24}$ ) bardzo często przynależnej do subkultur młodzieżowych. Możemy zaryzykować twierdzenie, że obecnie obieg kultury nieoficjalnej jest zjawiskiem, które wpisuje się w zakres pojęcia społeczeństwo obywatelskie, a rozważania na temat czasopism literackich wydawanych w nieoficjalnym obiegu kultury można odnieść do nakreślonego przez Habermasa modelu literackiej sfery publicznej.

Fanziny są laboratorium nowych form literackich, publikacjami, w których czytelnicy stawiają pierwsze kroki w literaturze, pisząc własne wariacje na temat już istniejących tekstów literackich. Podążając tropem metafory kapitału społecznego, można zauważyć, że $\mathrm{w}$ realiach powszechnego dostępu do Internetu elektroniczne wersje czasopisma tego rodzaju (tzw. e-ziny) stały się forum dialogu i amatorskiej krytyki literackiej, które doprowadzają do powstania alternatywnych form literackiego kontrkanonu. Istotnym elementem tej formy twórczości jest obecność bliskich styczności pomiędzy twórcami a odbiorcami tekstów kultury. W czasopismach funkcjonujących w ramach obiegu nieoficjalnego styczności takie stanowią fundament spontanicznych praktyk znaczeniotwórczych, nieregulowanej sfery ekspresji kulturalnej, w której powstaje kultura alternatywna oparta na wspólnych zainteresowaniach jej twórców i odbiorców, podzielanego przez nich kodu kulturowego. Tego rodzaju czasopisma literackie są zatem efektem akumulowania kapitału kulturowego, który zostaje zainwestowany w działalność w ramach alternatywnego obiegu kultury. W ten sposób, na podobieństwo języka, literatura jest żywym społecznym systemem in statu nascendi: systemem zawieszonym pomiędzy autorytetem zakumulowanego kapitału kulturowego a zmianą utożsamianą z oddolną działalnością literacką popularyzowaną za pośrednictwem czasopism literackich powstających $z$ dala od obiegu kultury oficjalnej.

W perspektywie modelu społecznego systemu literatury akumulacja rezerwuarów kapitału społecznego jest zapośredniczona

${ }^{24}$ M. Pęczak, Kilka uwag o trzech obiegach, „Więź” 1988, nr 2. 
przez czasopisma literackie pozostające poza oficjalnym obiegiem kultury symbolicznej. O ile oficjalne czasopisma literackie służyły reprodukcji systemu, o tyle prasa nieoficjalna stanowi motor zmian morfogenetycznych zachodzących w samym systemie literatury.

\section{REFERENCES}

Archer, Margaret. Realist Social Theory. The Morphogenetic Approach. Cambridge: Cambridge University Press, 1995.

Barthes, Roland. "Śmierć autora." Transl. Markowski, Michał P. Teksty drugie: teoria literatury, krytyka, interpretacja, no. 1/2, 1999.

Barthes, Roland. "Theory of the Text." Untying the Text: a Post-Structuralist Reader. Ed. Young, Robert. London-New York: Routledge, 1981.

Berger, Peter, Luckmann, Thomas. Społeczne tworzenie rzeczywistości. Traktat $z$ socjologii wiedzy, Transl. Niżnik, Józef. Warszawa: Wydawnictwo Naukowe PWN, 2010.

Bourdieu, Pierre, Passeron, Jean-Claude. Reprodukcja. Elementy teorii systemu nauczania. Transl. Neyman, Elżbieta. Warszawa: Wydawnictwo Naukowe PWN, 2006.

Bourdieu, Pierre. "The Forms of Capital." Handbook of Theory and Research for the Sociology of Education. Ed. Richardson, John G. New York: Greenwood, 1986.

Burzyńska, Anna, Markowski, Michał P. Teorie literatury XX wieku. Kraków: Wydawnictwo Znak, 2007.

Fukuyama, Francis. Trust: Social Virtues and the Creation of Prosperity. New York: Free Press, 1995.

Giddens, Anthony. Stanowienie społeczeństwa. Zarys teorii strukturyzacji. Transl. Amsterdamski, Stefan. Poznań: Wydawnictwo Zysk i S-ka, 2003.

Głażewski, Michał. "Teoria systemów autopojetycznych Niklasa Luhmanna między metafizyką a metabiologią." Przeglą Pedagogiczny, no. 1, 2009.

Głowacki, Bartosz. "Prasa trzeciego obiegu w kresie przełomu." Kultura - Media - Teologia, no. 3, 2010.

Habermas, Jürgen. Strukturalne przeobrażenia sfery publicznej. Transl. Lipnik, Wanda, Łukasiewicz, Małgorzata. Warszawa: Wydawnictwo Naukowe PWN, 2007.

Kalaga, Wojciech. "Culture and Signification." Britishness and Cultural Studies. Continuity and Change in Narrating the Nation. Ed. Knauer, Krzysztof, Murray, Simon. Katowice: Wydawnictwo Śląsk, 2000.

Kłoskowska, Antonina. Socjologia kultury. Warszawa: Wydawnictwo Naukowe PWN, 2007.

Ochman, Andrzej. "Zarys koncepcji Habermasowskiej sfery publicznej.” Studia Teologiczno-Historyczne Ślaska Opolskiego, no. 35, 2015.

Pęczak, Mirosław. “Kilka uwag o trzech obiegach.” Więź, no. 2, 1988. 
Putnam, Robert D. Bowling Alone: The Collapse and Revival of American Community. New York: Simon and Schuster, 2000.

Putnam, Robert D. Making Democracy Work: Civic Traditions in Modern Italy. Princeton: Princeton University Press, 1993.

Seligman, Adam B. The Problem of Trust. Princeton: Princeton University Press, 1997.

Sell, Robert D. Literature as Communication. The Foundations of Mediating Criticism. Amsterdam: John Benjamins Publishing Company, 2000.

Sztompka, Piotr. Society in Action. The Theory of Social Becoming. Cambridge: Polity Press, 1991.

Sztompka, Piotr. Socjologia. Analiza społeczeństwa. Kraków: Wydawnictwo Znak, 2007.

Sztompka, Piotr. Trust. A Sociological Theory. Cambridge: Cambridge University Press, 1999.

Świątkiewicz, Wojciech. Zróżnicowanie społeczne a uczestnictwo w kulturze. Katowice: Wydawnictwo Uniwersytetu Śląskiego, 1984. 